\title{
Cytotoxic effect of Spirulina platensis extract and Ulva compressa Linn. on cancer cell lines
}

\author{
*Maryati, M., Saifudin, A., Wahyuni, S., Rahmawati, J., Arrum, A., Priyunita, O., Aulia, \\ A., Putra, F.P.H., As'hari, Y., Rasyidah, U.M., Fadhilah, A., Muflihah, C.H. and \\ Da'I, M
}

Faculty of Pharmacy, Universitas Muhammadiyah Surakarta, Jalan A. Yani, Tromol Pos 1, Pabelan Kartasura, Surakarta, Central Java, Indonesia

\begin{abstract}
Article history:
Received: 19 November 2019

Received in revised form: 11

January 2020

Accepted: 15 January 2020

Available Online: 14 March 2020
\end{abstract}

Keywords:

Spirulina platensis,

Ulva compressa Linn,

Cytotoxic,

MTT method

DOI:

https://doi.org/10.26656/fr.2017.4(4).389

\begin{abstract}
Studies have shown that algae and seaweed have cytotoxic activity. This study was aimed to determine the cytotoxic activity of Spirulina platensis and Ulva compressa Linn. extracts against cancer cell lines. The cytotoxic activity of the extract was carried out using the MTT ((3-(4,5-dimetylthiazol-2-yl)-2,5-diphenyltetrazolium bromide) method. Results showed that the ethanol extract and methanol extract of Spirulina platensis have no cytotoxic effect against HeLa, WiDr, MCF7 and T47D cells. Water extract of Spirulina platensis had no cytotoxic activity on T47D and Vero cells. Water extracts of Spirulina platensis increase MCF7 cell growth. Phycocyanin powder also stimulates MCF7 cell growth. Ethanol extract of Ulva compressa Linn. exhibited potentially cytotoxic activity against MCF7 and moderate cytotoxic against WiDR cells with $\mathrm{IC}_{50}$ values are $31.86 \mu \mathrm{g} /$ $\mathrm{mL}$ and $104.93 \mu \mathrm{g} / \mathrm{mL}$, respectively. It can be concluded that extract of Spirulina platensis has no potential to be developed for cancer therapy. Ulva compressa Linn has the potential to be developed as an anti-cancer. Further research for study the mechanism of anticancer of Ulva compressa Linn on MCF7 was needed.
\end{abstract}

\section{Introduction}

Cancer is still the main cause of death in the world. In Indonesia, the prevalence of cancer showed an increase from 1.4 per thousand population in 2013 to 1.79 per thousand population in 2018. The highest rate was in the Yogyakarta with 4.86 per 1000 population, followed by West Sumatra 2.4779 per 1000 population and Gorontalo 2.44 per 1000 population. The high cost of chemotherapy, side effects and success treatment encourage efforts to find alternative medicines/ treatments from natural ingredients for cancer. One effort that can be taken is to explore the natural product, such as algae. Spirulina platensis is one type of algae that has received much attention because of the nutritional component and source of bioactive for therapy (Smiezeck et al., 2017).

The high nutritional content and therapeutic effects of Spirulina lead the use of Spirulina as a food supplement (Hosseini et al., 2013). Many studies indicated that Spirulina contains high concentrations of primary and secondary metabolites that are beneficial for health. Spirulina contains protein (55-70\% dry weight), fat, minerals, vitamins, pigments such as chlorophyll, Bcarotene, C-Phycocianin and allophycocyanin, omega 3 and omega 6 (Habib et al., 2008; Lordan et al., 2011). Several studies indicated that Spirulina or its extract could prevent or inhibit cancer growth (Hirahashi et al., 2002; Subashini et al., 2004). Spirulina is also known to have antibacterial activity and inhibits the replication of the Herpes simplex virus and HIV (Ayehunie et al., 1998; Ozdemir et al., 2004; El-Sheekh et al., 2014). Spirulina platensis have antioxidant, anti-inflamatory and immunomodulator activity (Bashandy et al., 2016; Wu et al., 2016).

Ulva compressa is also known to have cytotoxic activity against HeLa cells and Vero cells. Dichloromethane extract of Ulva compressa has cytotoxic activity against $\mathrm{HeLa}$ cells with $\mathrm{IC}_{50}$ values of $17.8 \mu \mathrm{g} / \mathrm{mL}$ and $28.1 \mu \mathrm{g} / \mathrm{mL}$ against Vero cells. The methanol fraction has cytotoxic activity against HeLa cells with an $\mathrm{IC}_{50}$ value of $45.5 \mu \mathrm{g} / \mathrm{mL}$ (Barreto et al., 2012).

In this study, the cytotoxic activity of Spirulina platensis extract and Ulva compressa extract on several 
cancer cell lines; Henrietta Lacks (HeLa), a human colon carcinoma cell (WiDr), ahuman breast cancer cell line (T47D) and Michigan Cancer Foundation-7 (MCF-7) cells were determined. Cytotoxic activity of samples was done using MTT assay.

\section{Materials and methods}

\subsection{Sample materials}

Spirulina platensis was produced by CV Neo Algae Sukoharjo Jawa Tengah Indonesia. Ulva compressa Linn. was obtained from Krakal Beach, Gunung Kidul, Yogyakarta and the identification of the algae was conducted by Abdul Razak Chasani S.Si., M.Si as a biologist in Plant Systematics Laboratory of the Faculty of Biology, Gadjah Mada University based on its morphology. The voucher specimen number is No 0933/ S.Tb./XII/2016. Phycocyanin powder obtained from PT Pico Biru Tekno, Bandung, Indonesia.

\subsection{Aqueous extraction}

Dried Spirulina platensis were blend into fine powder followed by extraction using sterile water (Czerwonkaa et al., 2018). Fifty grams of dried Spirulina platensis powder were suspended in $500 \mathrm{~mL}$ of sterile water (Bratachem) and extracted on shaker incubator (New Brunswick) for $24 \mathrm{hrs}$ at room temperature $\left(30^{\circ} \mathrm{C}\right)$. Then, the supernatant was separated by centrifugation (10 mins, $4000 \times \mathrm{g}$, RT), filtered through Whitman paper, and lyophilized using a Freeze Dryer (Christ, Alpha 1-2 Ldplus). Dried water extract was stored at $4^{\circ}$ C. The stock solution $(10 \mathrm{mg} / \mathrm{mL})$ was prepared directly before use by dissolving dried water extract in the cell culture medium.

\subsection{Non-agueous extraction}

Five hundred grams of Spirulina platensis powder were macerated in $5 \mathrm{~L} 96 \%$ ethanol and methanol for 3 days and occasionally stirred. Ulva compressa were macerated in $96 \%$ ethanol. The maceration is filtered through Whitman paper, then concentrated using rotary

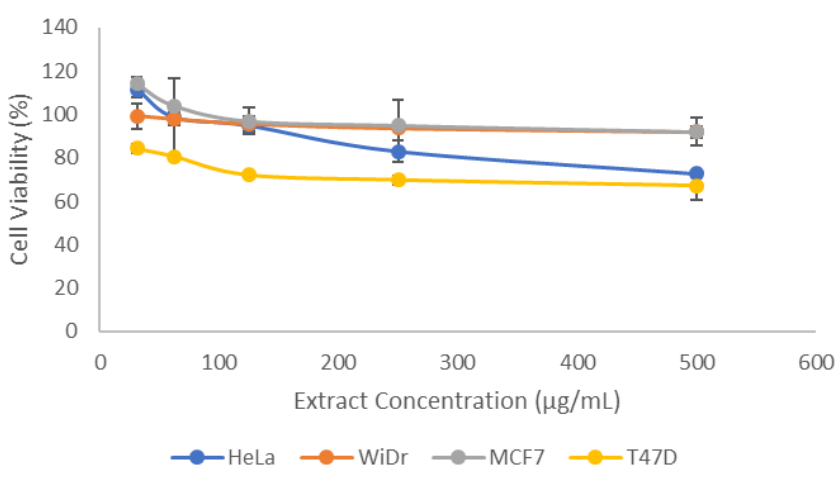

Figure 1. Effect of ethanol extract of Spirulina platensis on cancer cell lines. evaporator (Heidolph) and water bath to obtain a thick extract.

\subsection{Cytotoxic test}

HeLa, WiDr, MCF7, T47D and Vero cells were obtained from Parasitology Laboratory, Faculty of Medicine, Universitas Gadjah Mada, Indonesia. The 1.0 x $10^{4}$ cells/well were seeded into 96-well plate and incubated at $37^{\circ} \mathrm{C}$, incubator $\left(5 \% \mathrm{CO}_{2}\right)$ for $24 \mathrm{hrs}$. Cells were treated with various concentration of Spirulina platensis and Ulva compressa extract $(31.25 ; 62.5 ; 125$; $250 ; 500 \mu \mathrm{g} / \mathrm{mL}$ ). The treated cells were incubated in an incubator $\left(5 \% \mathrm{CO}_{2}\right)$ for $24 \mathrm{hrs}$ at $37^{\circ} \mathrm{C}$. Cells were washed with Phosphate Buffer Saline (PBS), then added with $0.5 \mathrm{mg} / \mathrm{mL}$ MTT (3-(4,5-dimetylthiazol-2-yl)-2,5diphenyltetrazolium bromide), incubated for 4 hours at $37^{\circ} \mathrm{C}$. Cells were added with regent stopper sodium dodecyl sufate ((SDS) reagent $(10 \%)$ in $\mathrm{HCl} 0.01 \mathrm{M})$, incubated overnight at $28^{\circ} \mathrm{C}$ (Handayani et al., 2017).

\subsection{Statistical analysis}

The data obtained was used to calculate the percentage of the viable cells using the following equation:

Viable cells $(\%)=\frac{(\text { abs. treated groups }- \text { abs. medium })}{(\text { abs. control cells }- \text { abs. } \text { medium })} \times 100 \%$

Furthermore, to calculate the $\mathrm{IC}_{50}$, a linear regression equation between the concentration of extract and percent of viable cells was formulated (CCRC, 2009).

\section{Results and discussion}

Cytotoxic activity of Spirulina platensis extract on HeLa, WiDr, MCF7 and T47 cells are shown in Figures 1 and 2 . At the highest concentration tested $(500 \mu \mathrm{gmL})$, ethanol extract inhibited the growth of HeLa, WiDr, MCF7 and T47D cells by $27.32 \%, 7.97 \%, 8.04 \%$ and $32.72 \%$, respectively (Table 1). At the highest concentration tested $(500 \mu \mathrm{g} / \mathrm{mL})$, methanol extract did not show any inhibition of HeLa and WiDr cells. In

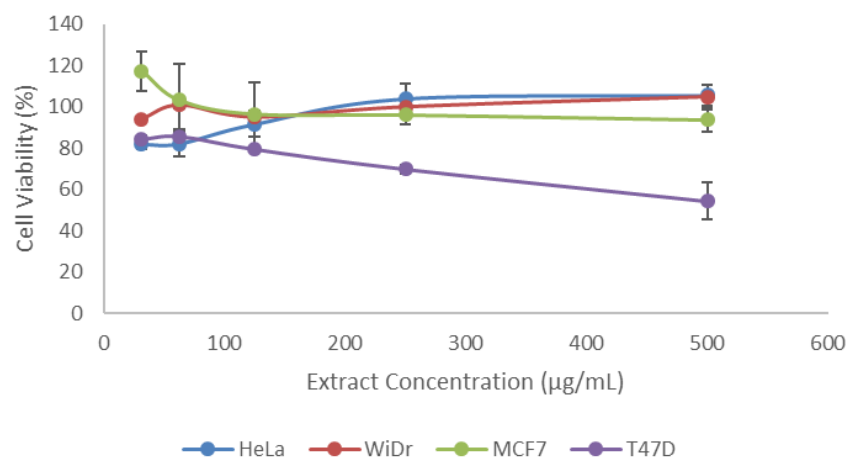

Figure 2. Effect of methanol extract of Spirulina platensis on cancer cells line. 
Table 1. Effect of ethanol extract of Spirulina platensis on cancer cell lines.

\begin{tabular}{ccccc}
\hline \multirow{2}{*}{ Concentration $(\mu \mathrm{g} / \mathrm{mL})$} & \multicolumn{4}{c}{ \% Cell viability $(\mathrm{X} \pm \mathrm{SD})$} \\
\cline { 2 - 5 } 31.25 & $111.547 \pm 3.907$ & $99.20 \pm 5.67$ & $114.014 \pm 2.89$ & $84.232 \pm 1.997$ \\
62.5 & $98.627 \pm 17.898$ & $97.81 \pm 2.94$ & $103.990 \pm 1.13$ & $80.655 \pm 0.576$ \\
125 & $94.859 \pm 3.356$ & $95.63 \pm 3.54$ & $96.912 \pm 6.24$ & $72.116 \pm 0.427$ \\
250 & $82.978 \pm 5.018$ & $93.68 \pm 0.76$ & $94.907 \pm 11.57$ & $69.837 \pm 2.038$ \\
500 & $72.673 \pm 1.384$ & $92.03 \pm 6.31$ & $91.963 \pm 2.50$ & $67.280 \pm 6.727$ \\
\hline \multirow{2}{*}{ Table 2. Effect of methanol extract of Spirulina platensis on cancer cell lines. } & \\
\hline \multirow{2}{*}{ Concentration $(\mu \mathrm{g} / \mathrm{mL})$} & & $\%$ Cell viability $(\mathrm{X} \pm \mathrm{SD})$ & \\
\cline { 2 - 5 } & $\mathrm{HeLa}$ & $\mathrm{WiDr}$ & $\mathrm{MCF} 7$ & $\mathrm{~T} 47 \mathrm{D}$ \\
\hline 31.25 & $81.901 \pm 2.417$ & $94.27 \pm 0.41$ & $117.522 \pm 9.56$ & $84.174 \pm 2.068$ \\
62.5 & $82.132 \pm 6.140$ & $101.06 \pm 1.65$ & $103.301 \pm 17.79$ & $85.588 \pm 3.568$ \\
125 & $91.668 \pm 6.235$ & $95.21 \pm 1.38$ & $96.598 \pm 15.46$ & $79.414 \pm 1.164$ \\
500 & $104.049 \pm 7.393$ & $100.11 \pm 4.75$ & $96.160 \pm 4.27$ & $69.828 \pm 2.200$ \\
\hline
\end{tabular}

MCF7 cells were only able to inhibit growth by $6.33 \%$, while in T47D cells were able to inhibit by $45.6 \%$ (Table 2 ). From the data obtained, the $\mathrm{IC}_{50}$ value could not be calculated. The results of the Spirulina platensis ethanol extract are in line with previous research which indicated that the ethanol extract of Spirulina platensis has low cytotoxic activity on MDA-MB-231 breast cancer cells with an $\mathrm{IC}_{50}$ value of $700.28 \mu \mathrm{g} / \mathrm{mL}$ (Mekjaruskul et al., 2016).

The water extract was tested against T47D, MCF7 breast cancer cells and Vero cells. Results showed that the water extract also did not have cytotoxic activity. In this study, we found an interesting phenomenon. It was seen in MCF7 cells treated with water extracts. Increasing concentration of the water extract causes an increase in the percentage of living cells (Figure 3). MCF7 cells are cells that have estrogen receptors. From these results, we suspected that the water extract of Spirulina platensis was estrogenic material, then it would induce the growth of MCF7 cancer cells. These results were different from previous studies conducted on a commercial product water extract in China on A459 lung cancer cells. The results of the study mentioned that Spirulina water extract significantly decreased the

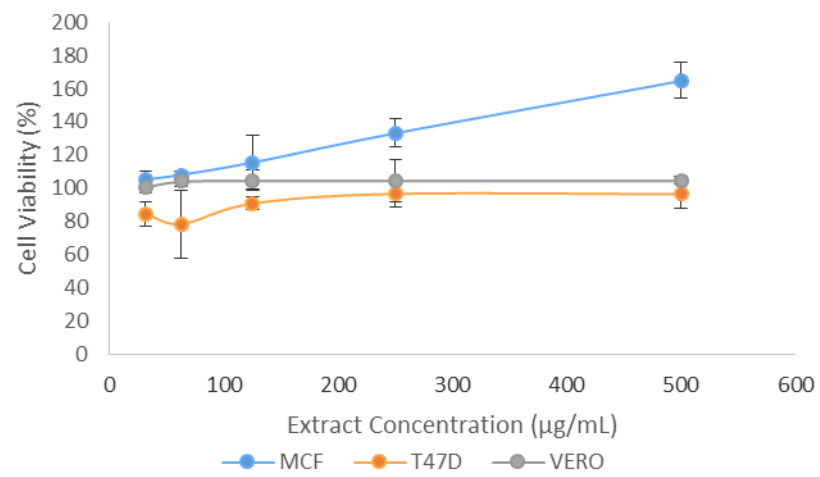

Figure 3. Effect of water extract of Spirulina platensis on WiDr and MCF7. percentage of living cells and proliferation of lung cancer cells A459 by the mechanism of cell cycle inhibition in the G1 phase and induction of apoptosis (Czerwonka et al., 2018). Other research indicated that Spirulina platensis filtrate which prepare using media for cell exhibited cytotoxic activity in Caco-2 colon cancer cells (Smieszek et al., 2016)

In this study, we also tested the phycocyanin powder produced by PT Pico Biru Tekno. Phycocyanin is known as an active compound from Spiruliana that has antitumor activity (Li et al., 2015), antioxidant activity (Patel et al., 2006) and induces apoptosis (Gantar et al., 2012). This phycocyanin was tested for its cytotoxic activity against MCF7 cells. The result showed that phycocyanin powder did not have cytotoxic activity against MCF7 cells, but instead stimulated the growth of MCF7 cells (Figure 4). This result is the same as the effect of Spirulina platensis water extract on MCF7 cells.

We also determine the cytotoxic effect of Ulva compressa Linn. Results showed that the ethanol extract of Ulva compressa Linn has potentially cytotoxic activity against MCF7 with $\mathrm{IC}_{50}$ of $31.86 \mu \mathrm{g} / \mathrm{mL}$ and

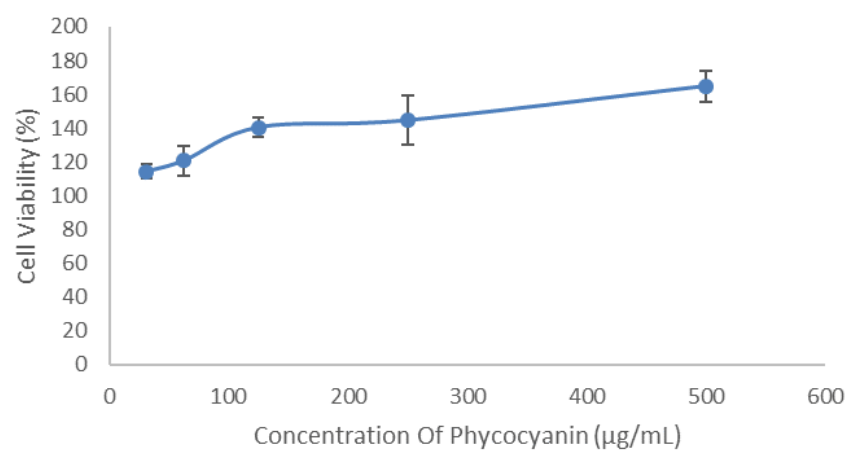

Figure 4. Effect of Phycocyanin on MCF7 cells. 
Table 3. Effect of ethanol extract of Ulva compressa Linn. on WiDr and MCF7 cells

\begin{tabular}{ccccc}
\hline \multirow{2}{*}{ Concentration $(\mu \mathrm{g} / \mathrm{mL})$} & \multicolumn{2}{c}{$\%$ Viability \pm SD } & \multicolumn{2}{c}{$\mathrm{IC}_{50}(\mu \mathrm{g} / \mathrm{mL})$} \\
\cline { 2 - 5 } & MCF7 & WiDr & MCF7 & WiDr \\
\hline 250 & $9.00 \pm 0.28$ & $8.78 \pm 1.69$ & 31.86 & \\
125 & $22.88 \pm 2.13$ & $57.74 \pm 1.59$ & & \\
62.5 & $40.20 \pm 1.39$ & $78.38 \pm 6.85$ & & \\
31.25 & $56.35 \pm 3.33$ & $93.33 \pm 5.65$ & & \\
\hline
\end{tabular}

moderate cytotoxic activity against WiDr cells with $\mathrm{IC}_{50}$ value of $104.93 \mu \mathrm{g} / \mathrm{mL}$, Figure 5 and Table 3). The cytotoxic categories were based on Prayong et al. (2007). Treatment using ethanol extracts cause morphological changes in MCF7 cells and WiDr. Figure 1 shows that the MCF7 cells before treated were oval shaped and looked transparent while cells, after treated with extracts, were seen to have changes in cell shape and darkness (Figure 6).

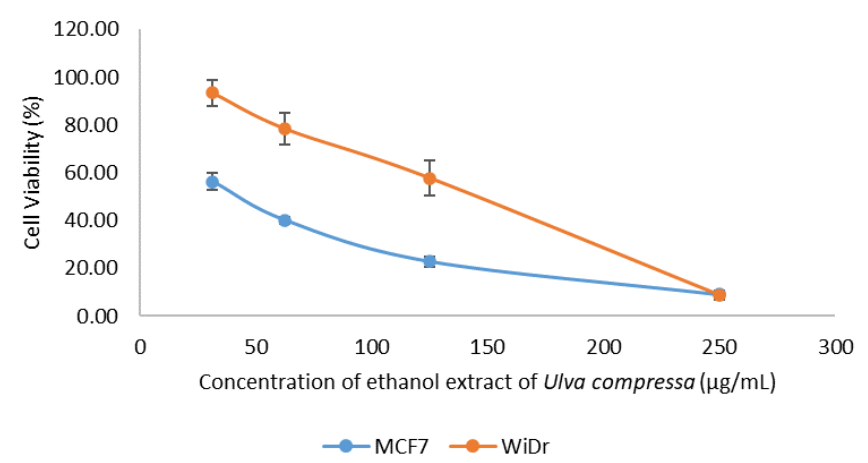

Figure 5. Effect of ethanol extract of Ulva compressa Linn. on WiDr and MCF7 cells

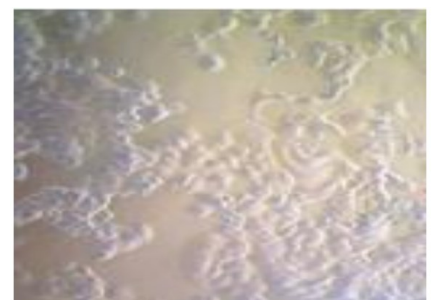

A

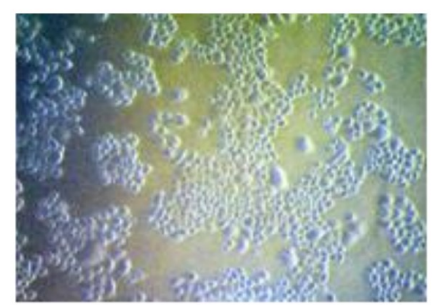

C

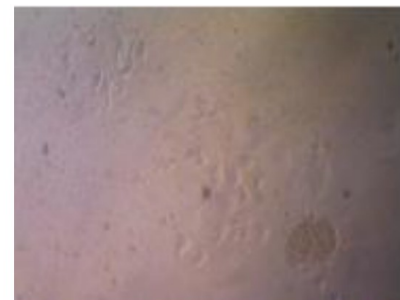

B

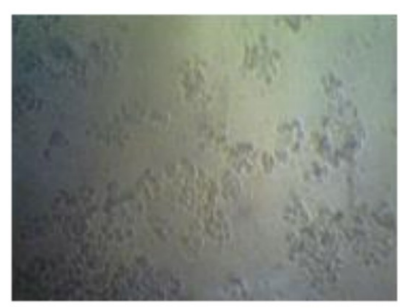

D
Figure 6. Morphology of MCF7 and WiDr cell before and after treatment at $250 \mu \mathrm{g} / \mathrm{mL}$ of Ulva compressa Linn extract. MCF7 cells before being treated (A) were oval shaped and looked transparent while cells after treated (B) with extracts were seen to have changes in cell shape and darkness. WiDr cells before being treated $(\mathrm{C})$ were round and clear while after the ethanol extract treatment (D), the cells were irregular in shape and dark in color.

Previous research showed that other green algae which have the same genus with Ulva compressa, Ulva fasciata Linn, contained phenol derivatives (Wikanta et al., 2012), sesquiterpen (Lee et al., 2013) and carotenoids which have anti-cancer activity (Baz et al., 2014). The algae also exhibited antioxidant and antiinflammatory activity (Wikanta et al., 2012; Lee et al., 2013; Baz et al., 2014). Research shows that hexane fraction of green algae has cytotoxic activity against T47D cells with $\mathrm{IC}_{50}$ values of $28.7 \mathrm{ppm}$ and against HeLa cells of 25.6 ppm (Marraskuranto et al., 2008). The ethyl acetate fraction Ulva fasciata is able to induce apoptosis in CaSki and MCF7 cells (Wikanta et al., 2012). The ethanol extract of Ulva fasciata was able to induce apoptosis of colon cancer cells in HCT 116 by $50 \%$ at a concentration of $200 \mu \mathrm{g} / \mathrm{mL}$, through a mechanism of decreased expression of Bcl-2, changes in mitochondrial permeability and activation of caspase- 9 and caspase-3 (Ryu et al., 2013).

\section{Conclusion}

Spirulina platensis produced by CV Neo Algae has no potential to be developed for cancer therapy. The use of food supplements containing Spirulina platensis produced by CV Neo Algae in breast cancer patients is not recommended because it can induce the growth of cancer cells. Ulva compressa has the potential cytotoxic activity against MCF7 with $\mathrm{IC}_{50}$ of $31.86 \mu \mathrm{g} / \mathrm{mL}$ and moderate cytotoxic activity against WiDr cells with $\mathrm{IC}_{50}$ value of $104.93 \mu \mathrm{g} / \mathrm{mL}$. Further research for study the mechanism of anticancer of Ulva compressa Linn on MCF7 was needed.

\section{Conflict of Interest}

The authors declare no conflict of interest.

\section{Acknowledgments}

The authors would like to express our gratitude to the Directorate of Research and Community ServiceMinistry of Research, Technology, and Higher Education for funding this research.

\section{References}

Ayehunie, S., Belay, A., Baba, T.W. and Ruprecht, R.M. (1998). Inhibition of HIV-1 replication by an aqueous extract of Spirulina platensis (Arthrospira 
platensis). Journal of Acquired Immune Deficiency Syndrome Human Retrovirology, 18, 7-12. https:// doi.org/10.1097/00042560-199805010-00002

Barreto, M.C., Mendonça, E., Gouveia, V., Anjos, C., Medeiros, J.S. and Seca, M.L. (2012). Macroalgae from S. Miguel Island as a potential source of antiproliferative and antioxidant products. Arquipelago. Life and Marine Sciences, 29, 53-58.

Baz, E., El-baroty, Ibrahim, Abd and Baky (2014). Cytotoxicity, Antioxidants and Antimicrobial Activities of Lipids Extracted from Some Marine Algae. Aquaculture Research and Development, 5 (7), 1-5.

Bashandy, S.A.E., El Awdan, S.A., Ebaid, H. and Alhazza, I.M. (2016). Antioxidant Potential of Spirulina platensis Mitigates Oxidative Stress and Reprotoxicity Induced by Sodium Arsenite in Male Rats. Oxidative Medicine Cellular Longevity, 2016, 7174351. https://doi.org/10.1155/2016/7174351

Czerwonkaa, A., Kaławaja, K., Sławińska-Brychb, A., Lemieszekc, M., Bartnikd, M., Wojtanowskid, K., Zdzisińskaa, B. and Rzeskia, W. (2018). Anticancer effect of the water extract of a commercial Spirulina (Arthrospira platensis) product on the human lung cancer A549 cell line. Biomedicine Pharmacotherapy, 106, 292-302. https:// doi.org/10.1016/j.biopha.2018.06.116

El-Sheekh, M.M., Daboor, S.M., Swelim, M.A. and Mohamed, S. (2014). Production and characterization of antimicrobial active substance from Spirulina platensis. Iran Journal of Microbiology, 6(2), 112-119.

Gantar, M. and Dhandayuthapani, S.R.A. (2012). Phycocyanin induces apoptosis and enhances the effect of topotecan on prostate cell line LNCaP. Journal of Medicinal Food, 15, 1091-1095. https:// doi.org/10.1089/jmf.2012.0123

Handayani, S., Susidarti, R.A., Jenie, R.I. and Meiyanto, E. (2017). Two Active Compounds from Caesalpinia sappan L. In Combination with Cisplatin Synergistically Induce Apoptosis and Cell Cycle Arrest on WiDr Cells. Advanced Pharmaceutical Bulletin, 7(3), 375-380. https:// doi.org/10.15171/apb.2017.045

Hosseini, S.M., Shahbazizadeh, S., Khosravi-Darani, K. and Mozafari., M.R. (2013). Spirulina paltensis: Food and Function. Current Nutrition and Food Science, 9(3), 189-193. https:// doi.org/10.2174/1573401311309030003

Lee, J.C., Hou, M.F., Huang, H.W., Chang, F.R., Yeh, C.C. and Tang, J.Y. (2013). Marine Algal Natural Products Anti-oxidative, Anti-Inflammatory, and
Anti Cancer Properties. Cancer Cell International, 13, 55. https://doi.org/10.1186/1475-2867-13-55

Hirahashi, T., Matsumoto, M., Hazeki, K., Saeki, Y., Ui, M. and Seya, T. (2002) Activation of the human innate immune system by Spirulina: Augmentation of interferon production and NK cytotoxicity by oral administration of hot water extract of Spirulina platensis. International Immunopharmacology, 2(4), 423-434. https://doi.org/10.1016/S1567-5769(01) 00166-7

Li, B., Gao, M.H., Chu, X.M., Teng, L., Lv, C.Y. and Yang, P.Y.Q. (2015). The synergistic antitumor effects of all-trans retinoic acid and C-phycocyanin on the lung cancer A549 cells in vitro and in vivo. European Journal of Pharmacology, 749,107-114. https://doi.org/10.1016/j.ejphar.2015.01.009

Lordan, S., Ross, R.P. and Stanton, C. (2011). Marine bioactives as functional food ingredients: Potential to reduce the incidence of chronic diseases. Marine Drugs, 9(6), 1056-1100. https://doi.org/10.3390/ md9061056

Marraskuranto, E., Fajarningsih, N.D., Indra Januar, H. and Wikanta, D.T. (2008). Aktivitas Antitumor (HeLa dan T47D) dan Antioksidan Ekstrak Makroalga Hijau Ulva fasciata. Jurnal Pascapanen dan Bioteknologi Kelautan dan Perikanan, 3(2), 107 -112. https://doi.org/10.15578/jpbkp.v3i2.21

Mekjaruskul, C., Fangkrathok, N. and Sripandikulchai, B. (2016). Antioxidative and anticancer activities of selected microalgae extracts isolated from east coast of Thailand presented at International Conference on Natural Porducts for Helath and Beauty (NATPRO6). Thailand: Khan Kaen University.

Ozdemir, G., Karabay, N.U., Dalay, M.C. and Pazarbasi B. (2004) Antibacterial activity of volatile components and various extracts of Spirulina platensis. Phytotherapy Research, 18(9), 754-757. https://doi.org/10.1002/ptr.1541

Habib, M.A., Parvin, M., Huntington, T. and Hasan, M. (2008). A review on culture, production and use of Spirulina as food for humans and feeds for domestic animals and fish. FAO Fisheries and Aquaculture Circular No. 1034. FIMA/C1034. Rome, Italy: FAO.

Patel, A., Mishra, S. and Ghosh, P.K. (2006). Antioxidant potential of C-phycocyanin isolated from cyanobacterial species Lyngbya, Phormidium and Spirulina spp. Indian Journal of Biochemistry and Biophysics, 43(1), 25-31

Prayong, P., Barusrux, S. and Weerapreeyakul, N. (2008). Cytotoxic activity screening of some indigenous Thai plants. Fitoterapia, 79(7), 598-601. https://doi.org/10.1016/j.fitote.2008.06.007 
Ryu, M.J., Kim, A.D., Kang, K.A., Chung, H.S., Kim, H.S., Suh, I.S., Chang, W.Y. and Hyun, J.W. (2013), The green algae Ulva fasciata Delile extract induces apoptotic cell death in human colon cancer cells. In Vitro Cellular and Developmental Biology - Animal, 49, 74-81. https://doi.org/10.1007/s11626-012-95473

Smieszek, A., Giezek, E., Chrapiec, M., Murat, M., Mucha, A., Michalak, I. and Marycz, K. (2017). The influence of Spirulina platensis filtrates on caco-2 proliferative activity and expression of apoptosisrelated microRNAs and mRNA. Marine Drugs, 15 (3), 65. https://doi.org/10.3390/md15030065

Wikanta, T., Rasyidin, M., Rahayu, L. and Pratitis, A. (2012). Aktivitas Sitotoksik dan Induksi Apoptosis dari Ekstrak Etil Asetat Ulva fasciata Delile Terhadap Sek CaSki dan Sel MCF-7. Jurnal Pascapanen dan Bioteknologi Kelautan dan Perikanan, 7(2), 87-96. https://doi.org/10.15578/ jpbkp.v7i2.72 